In all these problems it has to be remembered that we can never see the original sediment, but examination of the material in its completely unweathered form is a stage nearer this ideal. The problem might be further considered in the light of samples from deep borings.

\title{
REFERENCES
}

Hallam, A., 1957. Primary Origin of the Limestone-Shale Rhythm in the British Lower Lias. Geol. Mag., xciv, 175-6.

Kent, P. E., 1936. The Formation of the Hydraulic Limestones of the Lower Lias. Geol. Mag., lxxiii, 476-8.

- 1937. The Lower Lias of South Nottinghamshire. Proc. Geol. Assoc., xlviii, $163-174$.

Simpson, S., 1957. On the Trace-Fossil Chondrites, Quart. Journ. Geol. Soc., xcii, 475-500.

Trueman, A. E., 1915. The Fauna of the Hydraulic Limestones in South Notts. Geol. Mag., lii, 150-52.

38 RODNEY ROAD,

WEST BRIDGFORD.

14th September, 1957.

\section{THE LUSTLEIGH FAULT IN NORTH-EAST DARTMOOR}

SIR,-In his recent paper on the north-westerly trending Lustleigh faultzone in Devonshire, Dr. Blyth (1957) adds little to what was already known, although he has drawn attention to an important line of dislocation which is not even shown as such on the New Series one-inch maps of the Geological Survey.

The author, in a brief discussion of the age of the faults, says " it is possible that the faulting is entirely of Tertiary age" although the fractures "may have been initiated much earlier, in the closing stages of the Armorican orogeny but following the intrusion of the Dartmoor granite" (p. 296). In this connection, any evidence of mineralization in the fault-zone, of which Dr. Blyth makes no mention, and particularly the formation of the economic minerals, would be of the utmost importance.

The paper is largely concerned with the passage of the fault-zone through the granite, where, for example, slickensided surfaces might be expected to be common, and it is perhaps surprising that the author is unable to be more specific about the actual directions of movement.

On the western side of Dartmoor, between that granite mass and the very much smaller Gunnislake granite, the post-granite faults, frequently mineralized, appear to occur in essentially two sets, an older east-west set and a younger set trending between north-south and north-west-south-east, corresponding in trend respectively to the earlier tin and copper lodes and the later lead-bearing cross-courses. However, not all the lodes are faults and not all the east-west faults are lodes. Data on this fault-system has been largely obtained from a study of the plans of the abandoned metal mines, permission to examine which being kindly given by the Ministry of Fuel and Power.

The younger set of faults is especially interesting. Of these, those with a more north-westerly trend appear to be essentially normal faults. In the country-rocks east of Tavistock eastwards to the margin of the Dartmoor granite they have a dominant westerly hade at angles up to $40^{\circ}$, whilst in Tavistock itself and probably westwards to the Gunnislake granite they have a dominant easterly hade, again at angles up to $40^{\circ}$. This pattern would suggest trough-faulting between the two exposed granites. Those faults with a more northerly trend are present in the ground east and north-east of Tavistock where the available evidence suggests that they are sinistral tear 
faults hading westwards at angles up to about $20^{\circ}$ and branching off from the normal faults.

Taken together, all the evidence shows that the faulting was initiated during the latest phase of the cooling and consolidation of the granite, and that it is most likely due to uplift of the granite. It is interesting to recall that Collins (1902, p. 712) remarked on the "trough-like drop of the ground between the granite masses" and showed this in a diagrammatic section.

It is clear that the final phase in the deformation history of South-West England was one of extensive faulting, resulting in the rocks being cut up into a number of small blocks. What is particularly interesting in the Bodmin Moor-Dartmoor region is the dominance of the north-west-south-east faults and the apparent general absence of north-east-south-west faults, although in the Tintagel area, according to Wilson (1951, p. 420), the late normal faults have this latter trend.

\section{REFERENCES}

Blyth, F. G. H., 1957. The Lustleigh fault in North-East Dartmoor. Geol. Mag., xciv, 291-6.

Collins, J. H., 1902. Notes on the principal lead-bearing lodes of the West of England. Trans. Roy. Soc. Geol. Cornwall, xii, 683-718.

Wilson, G., 1950. The tectonics of the Tintagel area, North Cornwall. Quart. Journ. Geol. Soc., cvi, 393-432.

N. E. Butcher.

Geology Department,

THE UNIVERSITY,

READING.

12th September, 1957.

\section{DETERMINATION OF [001] AXES IN MUSCOVITE.}

Owing to an unfortunate oversight there is a printing error in the letter under this heading published in the last number of the Geological Magazine. From line 13 to line 70 all references to [001] should read (001).

In line 76, [001] should be followed by the word " axes".

\section{PUBLICATIONS RECEIVED}

F. J. North. Sunken Cities. pp. 256, with 17 text-figs. and 13 plates. University of Wales Press, Cardiff, 1957. Price $18 s$.

N. L. Bowen. The Evolution of the Igneous Rocks. pp. $332+82$ text-figs. Dover Publications, Inc., New York, 1956 (Vision Press, Ltd., London). Price: cloth 30 s., paper $15 s$.

W. M. Davis. Geographical Essays. pp. $777+130$ text-figs. Dover Publications Inc., New York, 1954 (Vision Press, Ltd., London). Price 24s.

B. GUTENBERG (Edit.). Internal Constitution of the Earth. pp. $439+43$ text-figs. Dover Publications, Inc., New York, 1951 (Vision Press, Ltd., London). Price 20s.

G. A. EIBY. Earthquakes. pp. 168 with 54 text-figs. and 32 pls. Frederick Muller, Ltd., London, 1957. Price 21s.

R. D. NinINGer (Edit.). Exploration for Nuclear Raw Materials. pp. xv + 293 with numerous text-figs. Macmillan and Co., Ltd., London, 1957. Price 55s. 